\title{
Foundation or Fragment of Local Democracy? Empirically Assessing the Roles of Local Councillors in Belgian Governance
}

\author{
Tom Verhelst, Herwig REynAert \& KRISTOF SteyVERS
}

\begin{abstract}
It is often argued that local governance conflicts with the prescribed functioning of local councillors. We could wonder if councillors have become fragments of local democracy, rather than the foundation they are supposed to be. This article empirically assesses the classic role-set (representation, policy, control) of local councillors in Belgian governance. Besides pointing to a gap between theory and practice, it underlines a substantial discrepancy between councillors' role attitude and subsequent behaviour. This democratic deficit seems mainly due to the informal decisionmaking culture in Belgian (local) politics, i.e. the dominance of the executive and stringent party discipline.
\end{abstract}

KEYWORDS: $\bullet$ local councillors $\bullet$ role-set $\bullet$ governance $\bullet$ democratic deficit $\bullet$ Belgium

Correspondence AdDress: Tom Verhelst, Centre for Local Politics, Department of Political Science, Ghent University, Universiteitstraat 8, 9000 Ghent, Belgium, email: tom.verhelst@ugent.be. Herwig Reynaert, Ph.D., Centre for Local Politics, Department of Political Science, Ghent University, Universiteitstraat 8, 9000 Ghent, Belgium, email: herwig.reynaert@ugent.be. Kristof Steyvers, Ph.D., Centre for Local Politics, Department of Political Science, Ghent University, Universiteitstraat 8, 9000 Ghent, Belgium, email: kristof.steyvers@ugent.be. 


\section{Introduction: From Foundation to Fragment... and Back?}

Network society and representative politics cannot live together, nor can they stay apart (Hendriks, 2002). It is often claimed that the shift from government to governance has had a fundamental impact on the institutions of local representative democracy (Pratchet, 1999; Hansen, 2005). Particularly the local council and the councillors would be affected (Hendriks, 2002; Sörensen, 2006). Indeed, the municipal council is historically conceived as the heart of local representative democracy along the lines of classic institutionalist parliamentary theory (Andrew \& Goldsmith, 1998). Councillors are supposed to personalize this political primacy based on the prevalence of the 'layman rule' in the Belgian local government (Mouritzen \& Svara, 2002). Hence, they are considered to be the foundation of local democracy.

This classic institutionalisation was envisaged to ensure traditional democratic government. However, the emergence of governance conflicted with the institutionalisation. Governance originated from the perceived government failure in dealing with complex problems (e.g. the reformed welfare state, issues of scale, the individualization of citizens) that involve different and often conflicting values (Klijn \& Koppenjan, 2000; Sörensen, 2006; Steyvers et al., 2006; Klijn, 2008). These challenging issues called for local policy coordination that included different actors at different levels, both public and private, incorporating those different values (Klijn, 2008). Consequently, local councillors were no longer the sole sovereign rulers in local politics and they lost their political primacy (Sörensen, 2006). Councillors therefore associate governance with losing power (Aars \& Fimreite, 2005). In Belgium, the emergence and growth of policynetworks placed these layman-politicians under pressure to the extent of being "marginalized" (De Rynck \& Voets, 2006: 60). Instead of acting as the foundation of local democracy, councillors may have become fragments of the latter: "more and more, ordinary councillors find themselves playing a role that implies simply overlooking from afar the political decisions decided upon, whilst they are increasingly removed from the reality of those decisions" (Rao, cited in Guérin \& Kerrouche, 2008: 183). This alleged democratic deficit might be a good example of what Pratchett (1999) has called the failing government institutions in governance. ${ }^{1}$

Since this debate touches upon some fundamental principles of local democracy, there is a growing concern - both theoretical and legal - about the expected behaviour of councillors (Tops \& Zouridis, 2002). As a response, "a search is on for new ways and means to bring elected councillors 'back on stage' and to the centre of local decision and policy making" (Hansen, 2001: 119). Belgian reforms at the turn of the millennium tried to strengthen the position of local councillors as well. For instance, in Flanders the council got authorized to elect its own president 
and councillors acquired agenda-setting rights whilst in Wallonia a constructive motion of distrust vis-à-vis the executive has been introduced. Re-empowering the council and councillors was thus an explicit goal of the new regional local government acts (Suykens, 2001; Pilet, 2008). ${ }^{2}$ However, in spite of the promising ambitions of these reforms, results seem to be more of a renovation than the real revolution that was deemed necessary to change things around. We feel that in order to implement successful changes, a thorough empirical analysis of the problem and its causes is indispensable first. Yet, the alleged democratic deficit of councillors' defective role-fulfilment has been rarely scrutinized empirically. Although there is a rapidly growing body of literature concerning governance (Klijn, 2008), it often focuses only on political leaders (see Steyvers et al., 2006 for Belgium; or Bäck et al., 2006 for a comparative European perspective). Still, Aars and Fimreite (2005) stress the importance of empirically studying the role of local councillors in governance. Furthermore, studies who focus on local councillors in governance often take a qualitative approach (Klijn, 2008). In Belgian literature empirical assessments of local councillor roles in governance seem to be scarce as well. This article tries to fill this gap by assessing the roles of local councillors in Belgium, both theoretically and empirically, inscribing it in the 'governing tradition' of governance studies. As such it focuses on the connection of governance networks to traditional institutions (Klijn, 2008). Do local councillors in Belgian governance act as the foundation of local democracy or have they rather evolved to fragments of it?

\section{Research Goals, Methods and Data}

The symbolic nature of this research problem requires us to specify precise research goals and derived measurable questions. The goal of this article is twofold: (1) it explores local councillor roles in practice and (2) exposes their underlying factors. First, we describe the role attitude and behaviour of Belgian local councillors by comparing empirical self-evaluations with formal-legal demands. As such we are able to refute the claim that Belgian local councillors do not assume their assigned roles as political primate, i.e. testing the presumed democratic deficit in their functioning. We consider principles (role attitude) and practices (role behaviour); the two constituting aspects of a role, defined as "the sum of institutionalized expectations with regard to the behaviour of the actors in question" (Sörensen \& Torfing, 2003: 624). Indeed, several authors stress the importance of councillor attitudes as a prior step towards democratic role behaviour (Klijn \& Koppenjan, 2000; Denters \& Klok, 2003). This holds particularly true in governance: "what stands in the way for a strong representative democracy under conditions of governance is first and foremost the way many politicians perceive the politician's role" (Sörensen, 2006: 99). Furthermore, we address the discrepancy between both role-aspects by quantifying the difference in role attitude and behaviour. Second, we expose the underlying factors of this role 
attitude, behaviour and discrepancy. More specifically, we verify if place, personal characteristics and informal decision-making culture matter in predicting local councillor roles in Belgium, based on concrete research hypotheses.

Our data stem from the Belgian contribution to a European comparative research project that is concerned with municipal councils and councillors. ${ }^{3}$ After selecting 180 municipalities on the basis of a stratified random sample a questionnaire was sent out to all councillors of those municipalities - creating a representative sample of 4096 councillors. We ended up with a research population of 856 cases. ${ }^{4}$ The questions enquired upon personal assessments of the councillors' roles. Notwithstanding some degree of subjectivity that is inherent to all selfevaluations, results of this type of analysis often show to be consistent with more detailed counterparts of decision-making processes (Denters, 2006).

The article continues by outlining the formal role-set of local councillors in Belgium (section 3), before describing this role-set in practice (section 4). Afterwards, it discerns a set of factors that could account for the variance in councillor roles (section 5) before tackling the explanatory research goal in section 6. In the conclusion, general results are presented and some subsequent perspectives for the future are raised.

\section{The Classic Councillor Role Set}

The role of local councillors is to a large extent determined by the institution in which they function, i.e. the municipal council (Sörensen \& Torfing, 2003). As the only directly elected body of local democracy, the council's role is contingent upon local government's conception as "an important link between the politicaladministrative system and the citizens" (Vetter \& Kersting, 2003: 12). As such, all local governments serve two main functions: the production of public services for citizens (i.e. output-function), and the integration and education of citizens in politics (i.e. input-function). Whilst the former establishes local government as a first administration, the latter turns it into a democratic base (Steyvers \& Reynaert, 2003).

The demands for local governments to be both democratic and efficient are transposed to the classic role-set of local councillors. On the input-side of local government, councillors have a role as representatives of the citizens (Rao et al., 1994). They translate the needs and issues from society in political actions and establish a reliable and effective link between citizens and politics (Heywood, 2002). The output-function of local government results in the double role as administrator of local affairs (Rao et al., 1994). On one hand, councillors should set general policy goals and direct public service delivery. On the other hand, councillors are expected to control the implementation of local policy as well. The 
combination of representation, policy, and control has been crystallised as the councillors' classic role-set from the first local legislation up until the present-day. It theoretically puts councillors in charge of all aspects of municipal governance as "sovereign rulers who hold all the power, and, therefore, all the responsibility" (Sörensen \& Torfing, 2009: 254).

It is argued, however, that Belgian councillors fail to assume this designated roleset in practice, especially at the output-side of their mandate: "the municipal council no longer controls the executive and is failing to dominate the local policy process" (Steen \& Wille, 2005: 445). The representative role would be less affected (Kalk \& De Rynck, 2003) due to the nature of the Belgian local government. From a comparative perspective, Belgium is classified amongst the Southern-type countries in which the notion of 'political localism' prevails. Its local governments are conceived as political communities with a distinctive identity, rather than being first-hand service providers (Andrew \& Goldsmith, 1998; Steyvers, 2007).

\section{Between Principle and Practice: Role-Discrepancy of Local Councillors in Belgium}

The classic role-set of local councillors in Belgium entails three basic roles: representation, policy, and control. Our questionnaire included three statements that served as indicators for these roles: 'Representing the requests and issues emerging from the local society'; 'Defining the main goals of the municipal activity'; and 'Controlling the municipal activity'. The respondents were asked (1) to indicate the importance they personally attach to the roles, reflecting 'role attitude'; and (2) to assess their personal contribution to the roles, reflecting 'role behaviour'. Scores varied from 0 (no importance/contribution) to 4 (very high importance/contribution).

The results allow us to quantify the alleged democratic deficit in local councillors' role-fulfilment: (1) to what extent do they support their designated role-set and (2) to what extent do they act accordingly? Furthermore, we constructed a new variable ('role discrepancy') that reflects the discrepancy between role attitude and behaviour. Scores on this variable could vary from -4 (minimum score for attitude, maximum score for behaviour) to 4 (maximum score for attitude, minimum score for behaviour). Whilst negative scores do not pose many problems from a democratic point of view (as councillors still contribute to a task they deem less important), positive scores do: the respondent attaches importance to a task, but is not able to fulfil it to the same extent. Table 1 presents mean scores, standard deviations and support for the classic role-set in terms of attitude, behaviour and discrepancy. 
Table 1: Role attitude, behaviour and discrepancy of Belgian local councillors

\begin{tabular}{lccccccccc}
\hline & \multicolumn{3}{c}{ Attitude } & \multicolumn{3}{c}{ Behaviour } & \multicolumn{3}{c}{ Discrepancy } \\
\hline & $\mathbf{X}$ & $\mathbf{S}$ & $\mathbf{3 - 4}$ & $\mathbf{X}$ & $\mathbf{S}$ & $\mathbf{3 - 4}$ & $\mathbf{X}$ & $\mathbf{S}$ & $\mathbf{2 - 4}$ \\
& {$[\mathbf{0}-\mathbf{4}]$} & & $\mathbf{\%}$ & {$[\mathbf{0}-\mathbf{4}]$} & & & {$[\mathbf{- 4}-\mathbf{4}]$} & \\
\hline Representation & 3.3 & 0.7 & 88.3 & 2.8 & 0.8 & 66.3 & 0.5 & 0.9 & 11.8 \\
Policy & 3.1 & 0.9 & 77.9 & 2.2 & 1.1 & 39.2 & 0.9 & 1.2 & 27.2 \\
Control & 3.1 & 0.8 & 80.2 & 2.6 & 0.9 & 52.2 & 0.5 & 1.0 & 15.5 \\
\hline
\end{tabular}

(Representation: $\mathrm{N}=844,842,833$; Policy: $\mathrm{N}=836,841,826$; Control: $\mathrm{N}=839,846,830$ )

In terms of role attitude, councillors acknowledge their triple role as political primate. The representative role generates the strongest support, confirming theoretical arguments. The vast majority of Belgian councillors ( $88.3 \%)$ believe it is (very) important to represent requests and issues from local society. Furthermore, $77.9 \%$ of the councillors underline the importance of defining the main goals of municipal policy, while controlling this policy is an important task for $80.2 \%$ of the respondents. Thus, local councillors in Belgium principally comply with the notion of democratic foundation that theory and legislation impose on them.

However, the analysis of councillors' role behaviour shows a different picture. Whilst the general relation between the roles is confirmed, the substantial lower scores and larger mutual differences between the roles in practice are striking. The representative role is best fulfilled in practice too, followed by control and policy. Whereas still $66.3 \%$ of the councillors see themselves actually representing requests and issues from local society, only $52.2 \%$ of the respondents answer the same regarding control. Furthermore, no more than 39.2\% define their actual contribution to local policy making as (very) great. These results confirm the claim pointing to the limited influence of Belgian local councillors in practice. They do not seem to function as the democratic foundation, revealing a democratic deficit between theory and practice.

The third variable underscores the discrepancy between attitude and behaviour. Councillors face the lowest role discrepancy in terms of representation and control. Still, more than one out of ten councillors $(11.8 \%$ for representation and $15.5 \%$ for control) strongly feels that they cannot contribute as much to these roles as they would want to. The most problematic role is policy making: more than one out of four councillors (27.2\%) feel a strong discrepancy in this role. Hence local councillors in Belgium do not practice what they preach, reflecting a second democratic deficit. Besides the gap between theory and practice, the difference between councillors' attitude and behaviour is remarkable. In our view, the latter should cause even more concern, as it implies that certain factors hinder councillors in assuming their prescribed and internalized role-set. Scrutinizing these factors and their impact is the second, explanatory, goal of this article. 
In order to select the factors that could predict local councillors' role attitude, behaviour and discrepancy, we turn to both general evolutions in local governance and particular characteristics of Belgian (local) politics. First, we assess the questions if place and personal characteristics matter (see e.g. Rao et al., 1994). Evolutions on these levels could help to explain the influence of the shift to governance, which is claimed to have substantially exacerbated the problem of the councillors' role-fulfilment (Guérin \& Kerrouche, 2008). Afterwards, we verify the influence of the Belgian informal decision-making culture, for "successful reform depends as much on cultural change as on structural and procedural measures" (Steen \& Wille, 2005: 460). This factor acknowledges the historic continuity of local councillors' functioning in Belgium (see De Rynck, 2007). The selected variables serve as predictors for a regression analysis and are transposed to research hypotheses. The same hypotheses are applied to the analysis of both role attitude and behaviour, as these are supposed to coincide on a theoreticalformal base. On the other hand, we expect the analysis of role discrepancy, as a resultant of the empirical comparison of attitude and behaviour, to be somewhat different. For instance, one could expect the effect of one factor on role attitude being compensated or overturned by the impact of other factors on role behaviour, and vice versa. As such, we do not apply the hypotheses to the analysis of role discrepancy.

\section{Place}

According to traditional local government typologies, Belgian local governments have limited functions, low discretion, and high access to the centre (Page \& Goldsmith, 1987). Moreover, their input-function outweighs the output-oriented public service delivery, making them foremost the expression of local identity (Hesse \& Sharpe, 1991). Typologies are not always clear-cut, however, as especially federal countries are difficult to fit into the picture (Goldsmith \& Page, 2010). The Belgian federal state comprises three regions (Flanders, Wallonia and Brussels Capital) which are functionally and legally equal to each other - and to the federal state. Meanwhile, regionalization has been one of the most important political trends of the past decades in Belgium (Plees, 2005). Since the state reform of 2002, main local legislation powers have been transferred to the regions. Subsequent reforms revealed a diverging focus: whereas Flemish reforms were much more administration-driven, Brussels and Wallonia continue to advocate local governments' representative input-function (Pilet, 2008). This leads us to wonder whether Flanders is drifting away from the Southern system towards a more Northern public service-directed local government system, translated in new goals of efficiency and effectiveness. Therefore, 'region' is our first predictor: we expect that 'councillors from the Flemish region will tend more towards the output 
roles (H1a) but less towards the input role (H1b) than councillors from the other regions'.

A second place-bound predictor could be the scale of local government in terms of population numbers. Urbanization, albeit having longstanding historical roots, is considered to be one of the most influential evolutions in local government during the last fifty years (Denters \& Rose, 2005). Based on an efficiency-driven logic a gulf of amalgamations swept the European continent (Vetter \& Kersting, 2003). In Belgium the last round of amalgamations goes back to 1976-1982, reducing the number of municipalities from 2.586 to its current number of 589 (Plees, 2005). However, whereas urbanization may enhance the output-legitimacy of local government, it threatens to weaken the input-legitimacy alike. Especially in bigger cities, the stress on local councillors deems to make the municipal council a fragment of local democracy (Haus et al., 2005). Smaller municipalities, on the other hand, could facilitate representation through informal and personal contacts between citizens and politicians. We therefore hypothesize that 'councillors from bigger municipalities will tend more towards the output roles (H2a) but less towards the input role (H2b) than councillors from smaller municipalities'.

\section{Personal Characteristics}

Apart from socio-economic and political trends at the macro-level of local government, evolutions at the micro-level - meeting participatory and instrumental demands from citizens - could also impact upon councillors in governance (Denters \& Rose, 2005). Reforms introducing (elements of) direct democracy (e.g. local referenda, public meetings) sought to re-engage citizens in the political process, hence aimed at strengthening the input-legitimacy of local governance (Vetter \& Kersting, 2003). On the downside, directly empowering citizens impinges on the representative function of local councillors as intermediating agents between citizens and the state. Councillors' support for citizen participation ('participation') therefore serves as the third predictor in our model. We expect that 'councillors who support citizen participation will tend less towards the input role than councillors who support citizen participation to a lesser extent (H3)'.

Furthermore, citizens' instrumental demands for efficiency on the output-side of local governance led to the introduction of New Public Management-arrangements and inter-municipal co-operations, and instigated an increasing workload for councillors (Vetter \& Kersting, 2003; Denters \& Rose, 2005). The inherent requirement for technical skills and expertise resulted in the professionalisation of the local councillor (Cotta \& Best, 2000). In this context the concept refers to the increasing calibre of councillors which empowers them as actors in governance. Consequently, traditional qualities of representative politicians (voluntary base, legal equality and amateurism) lost their ground, and a 'new-style councillor' 
emerged - perceiving his mandate as a career or profession (Guérin \& Kerrouche, 2008). 'Professionalisation' in terms of education, profession and political experience is our fourth predictor. We hypothesize that 'professionalised councillors will tend more towards the output roles than less professionalised councillors (H4)'.

\section{Informal Decision-Making Culture}

Despite the plausible and universal influence of the abovementioned governancerelated factors, we should also consider the singularity of Belgian politics. Indeed, Belgian politics is marked by its informal way of decision-making. A first particular characteristic would be the influence of political parties who are "at the centre of the councillors assumptive world" (Copus, 2008: 602) without having a formal role-specification in local government legislation (De Rynck, 2000). As such, parties function as 'formalized informalities' (Copus, 2008). Political parties may enhance the democratic calibre of a system by harmonizing policy with public demand and acting as intermediary institutions (Putnam, 1976). However, the exceeding collusion of parties and government may transform representative democracies into "partitocracies" or party governments (De Winter \& Dumont, 2006: 957). Belgium is widely considered to be such a partitocracy (De Winter \& Dumont, 2006). Stringent party discipline can diminish the political debate if majority parties unilaterally take all important decisions (Steyvers et al., 2010). Accordingly, controlling local policy turns into a prerequisite for the opposition as members of the political majority will find it very hard to (publicly) march against the party orders. This 'majority logic' (belonging to the majority or opposition) is our fifth predictor. We presume that 'councillors from the majority will tend more towards policy making and representation (H5a) but less towards control (H5b) than councillors from the opposition'.

A second distinctive feature of Belgian politics is the dominance of the executive over the legislative body (Steyvers et al., 2010). Formally, the council instigates the executive (the Board of Mayor and Aldermen, BMA). The latter operates as a collegial body whilst its members retain their seats in the council (Mouritzen \& Svara, 2002). As such, the BMA should merely implement decisions taken by the council. In reality, however, this personal monism works the other way around (Steen \& Wille, 2005). While the BMA develops its own dynamics as a separate political body (functional dualism), the power-relation between council and executive is inverted. The executive often functions as the dominant decisionmaking body, surpassing or bypassing the council (Steyvers et al., 2010). Consequently, 'political mandate' (belonging to the BMA or not) is our final predictor. We assume that 'executive councillors will tend more towards policy making and representation (H6a) but less towards control (H6b) than nonexecutive councillors'. 
The final test results are shown in Figure 5 where we compare preferences for increased responsibility with the weight of local taxes in the local government budget. The hypothesis is that where a local government is allowed to raise its own revenue, it is likely to exercise a high level of discretion, thereby having a higher level of responsibility for the delivery of different functions. However, a high weight for local taxes in the budget does not mean that local government is strong vis-à-vis the central government because there are the European countries that get much of their budget from local taxes, yet they have a rather limited budget compared with that of central levels of government (e.g., Ireland and Belgium). The figure shows a small relationship between support for increasing the responsibilities of local authorities and the importance of local taxes, yet this relationship is only marginally significant. Again, if we consider only Western European countries, the relationship disappears.

\section{The Informal Decision-Making Culture Matters!}

Belgian local councillors are confronted with several evolutions in, and characteristics of the local government system in which they function. Eight factors $^{5}$ serve to predict scores on councillor roles (representation, policy, control) ${ }^{6}$ by means of a binary logistic regression analysis, presented in Table 2 . All variables have been re-coded in dummies (value 0 or 1) in order to capture maximal variance from a theoretical perspective. The data reflect the strength (Exp (B)) and significance (Sign) of the association between high scores on the predictors and high scores on role attitude, behaviour and discrepancy in terms of representation, policy and control. 


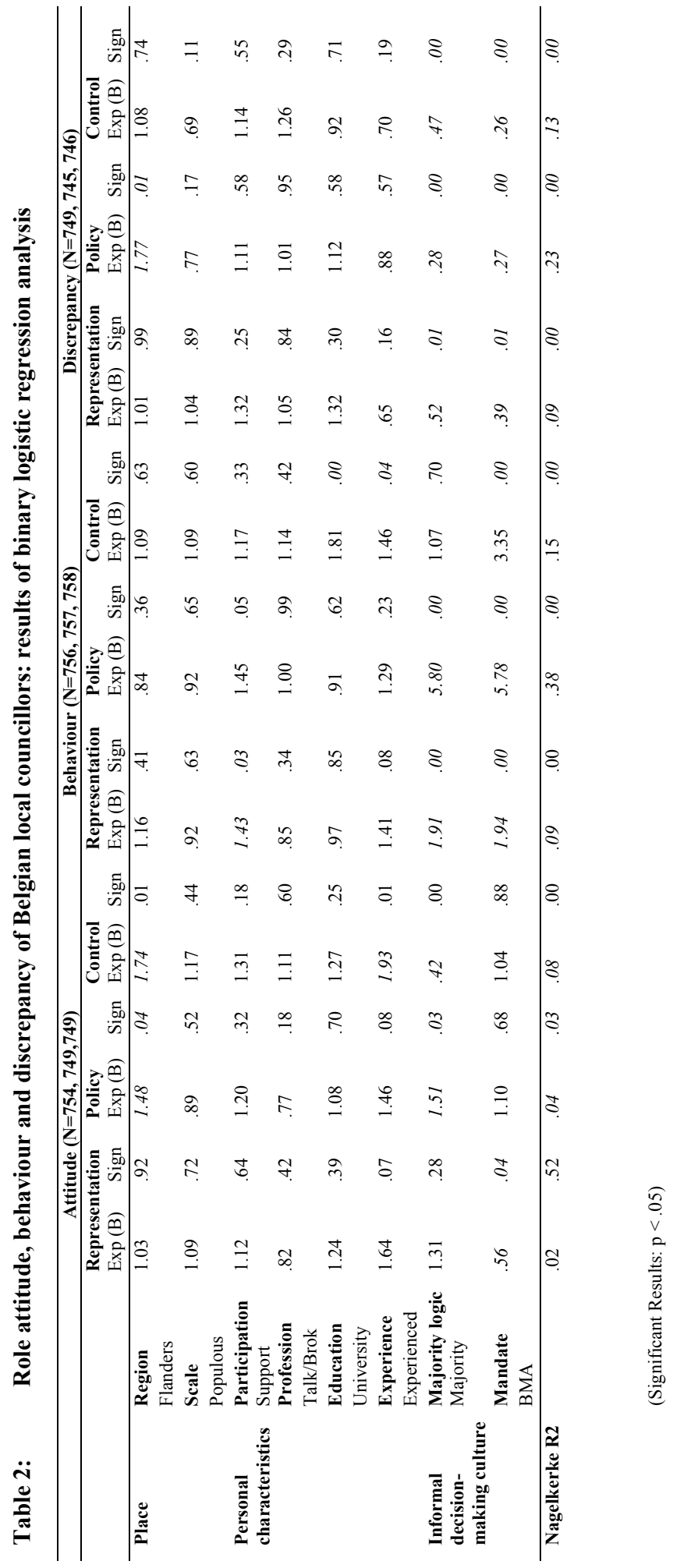


Regarding role attitude, the predictive value of the models is rather low. Representation is weakly (and not significantly) predicted by our independent variables, whilst results for policy and control are significant but only faintly stronger. Since role attitude is commonly shared amongst our research population (i.e. councillors supporting their three roles), results differ to a lesser extent according to evolutions in/and characteristics of Belgian governance. Looking at the influence of the predictors per analytical level, "place" only matters partially. Flemish councillors do attach more importance to the output roles, confirming hypothesis 1a, but value representation as much as councillors from Brussels and Wallonia, rejecting hypothesis $1 \mathrm{~b}$. 'Scale' does not matter in any significant manner, rejecting hypotheses $2 \mathrm{a}$ and $2 \mathrm{~b}$ as well. The second level, councillors' "personal characteristics", matter even less. Only 'experience' impacts significantly on 'control': experienced councillors support the control role almost twice as much as less experienced councillors. Consequently, we cannot accept hypothesis 3 and 4 either. Finally, does the "informal decision-making culture" act upon councillors' role attitude? Hypotheses $5 \mathrm{a}$ (partially) and especially $5 \mathrm{~b}$ can be accepted. Councillors from majority parties place significantly more importance to policy than councillors from the opposition, but no significant difference in terms of representation occurs. Opposition councillors put more than twice as much stress on control. Hypotheses $6 \mathrm{a}$ and $6 \mathrm{~b}$, however, cannot be confirmed. Executive councillors attach substantially less importance to representation than nonexecutives, whilst no significant results emerge concerning the output roles. Hence, the informal decision-making culture matters most with regard to role attitude, albeit this influence is not very strong and significant.

Do these findings apply to role behaviour as well? Considering the democratic deficit revealed in the descriptive analysis of role behaviour, the stronger results produced by the explanatory models seem legitimate. Representation, policy and control are (moderately) strongly predicted by the independent variables. "Place" first of all does not matter in predicting role behaviour of Belgian local councillors. Hypotheses 1a, 1b, 2a and 2b are thus rejected. Second, councillors' "personal characteristics" offer more explanatory value. Contrary to the expectation phrased in hypothesis 3, councillors who support direct citizen participation display more representative behaviour as well. Further, highly educated and experienced councillors contribute significantly more to controlling municipal policy. As the other expected relations are neither strong nor significant, we cannot accept hypothesis 4 . Third, the impact of both place and personal characteristics is outweighed by the "informal decision-making culture". Councillors from the majority and executives indicated to contribute almost twice as much to representation and almost six times as much to policy as nonexecutives and opposition councillors. Consequently, hypotheses 5a and 6a are confirmed. Whilst 'majority logic' does not affect control, rejecting hypothesis $5 \mathrm{~b}$, executives even contribute more than three times as much to control as non- 
executives, rejecting hypothesis $6 \mathrm{~b}$ as well. As such, the typical decision-making culture of Belgian local politics exceeds governance-related trends in predicting local councillors' role behaviour. Two formalized informalities, cutting across democratic principles and legal prescriptions, determine councillors' role behaviour and provoke a democratic deficit in councillors' functioning.

Finally, which factors account for the second democratic deficit, i.e. the role discrepancy that emerged from the empirical comparison of principal attitude and practical behaviour? All three models are (moderately) strong and significant, with policy exceeding control and representation in terms of the proportion of variance accounted for. The analysis per analytical level shows only one significant result at the macro-level "place". Flemish councillors feel a stronger discrepancy in their policy making role than councillors from Brussels and Wallonia. At the microlevel, the significant relations in the analyses from attitude and behaviour evaporate in the analysis of role discrepancy: "personal characteristics" do not determine whether a councillor faces a discrepancy between principle and practice. Consequently, the "informal decision-making culture" is the determining factor yet again. Both 'majority logic' and 'mandate' significantly and substantially determine if councillors experience a discrepancy between attitude and behaviour in terms of representation, policy, and control. The gap between the importance attached to representation and the extent to which this role is fulfilled in practice, is only half as strong for councillors from the majority and especially executive councillors compared to non-executives and opposition members. This implies that the discrepancy between attitude and behaviour is more than twice as strong for 'ordinary' councillors. Furthermore, the role-discrepancy in the policy making role is almost four times smaller for executives and majority councillors, whilst the analysis for control produces similar results. Thus, executives and councillors from the majority are far less subjected to the democratic deficit than their colleagues. They seem empowered to act in line with legal provisions and personal beliefs, i.e. being the foundation of local democracy. Besides, results for 'mandate' are even stronger than results for 'majority logic', implying that these factors enhance each other ${ }^{7}$. Majority councillors and particularly executives comprise a specific elite which is able to play its role to the detriment of the other councillors. Table 3 summarizes the total predictive value of our independent variables. 
Table 3: $\quad$ Strength of the individual predictors

\begin{tabular}{llc}
\hline Predictor & \multicolumn{1}{c}{ Analytical Level } & $\begin{array}{c}\text { Significant Relations } \\
{[\mathbf{X} / \mathbf{9}]}\end{array}$ \\
\hline Majority Logic & Informal decision-making culture & 7 \\
Mandate & Informal decision-making culture & 7 \\
Region & Place & 3 \\
Experience & Personal characteristics & 2 \\
Education & Personal characteristics & 1 \\
Participation & Personal characteristics & 1 \\
Profession & Personal characteristics & 0 \\
Scale & Place & 0 \\
\hline
\end{tabular}

A quick glance at the table immediately elucidates the factors that provoke the democratic deficit in local councillors' role-fulfilment. Whilst both "place" (3/18 significant relations, ratio 1:6) and especially "personal characteristics" of the councillors (4/36 significant relations, ratio 1:9) do not really seem to matter, the "informal decision-making culture" (14/18 significant relations, ratio 1:1.3) is very important. Subsequently, we would argue that the typical Belgian decisionmaking culture determines local councillors' functioning and the democratic deficit within, rather than the changed context of local governance.

\section{$7 \quad$ Conclusion}

This article was based on the claim that local councillors find it increasingly hard to function in their role as the foundation of local democracy in the complex government context of the $21^{\text {st }}$ century. In Belgium local councillors are conceived as the emanation of representative democracy. Hence their classic role-set of representation, policy and control should empower them as key actors in local government. However, it is often argued that the shift to local governance threatens to make councillors fragments of local democracy, failing to fulfil this role-set.

Our study designated that at least in terms of role attitude Belgian local councillors correspond to theoretical and legal demands. Councillors attach much importance to policy, control and especially representation. We did perceive a democratic deficit in their role behaviour, however. In practice, Belgian councillors contribute far less to their role-set than formally postulated. Furthermore, the comparison of attitude and behaviour resulted in a significant discrepancy as well. As such the democratic deficit is twofold: role behaviour deviates from theoretical and legal provisions, as well as from personal role attitudes. In our view attention should be directed to the underlying causes if councillors ought to be re-empowered in an effective way. 
Therefore, a regression analysis aimed to expose factors that determine local councillors' role-fulfilment, and consequently the democratic deficit within. Whereas governance-related factors such as place and personal councillor characteristics did not seem to matter that much, the archetypical informal decision-making culture in Belgian politics did very much. The executive dominance and the power of political parties - two formalized informalities overwrite both democratic theory and role attitude with a strong political ink. On one hand, a selective group of councillors obtains power to act as 'foundation' of local democracy, defining and controlling policy whilst representing requests and issues from society. On the other hand, ordinary councillors seem to be reduced to mere fellow travellers, if not 'fragments' of democracy due to factors that contradict the ideal and formal notion of democratic governance.

Based on these empirical findings, which perspectives for the future could be raised? If Belgian municipal councils and councillors are to be re-empowered as democratic foundation, further local government reforms seem inevitable. Literature distinguishes two paths to tackle this problem (Hendriks, 2002; De Rynck, 2007). The first turns to traditional institutional reforms, strengthening representative democracy and its actors. We could doubt, however, if the current path chosen by Belgian regional governments would be sufficient to achieve this goal. Not only seem councillors far from re-empowered at this moment, we expect that the effects of the implemented structural reforms will be insufficient to cope with the dominant influence of informal culture on the long haul as well. The introduction of 'dualism' could be part of the solution, as this system proved to be quite effective in the Netherlands (De Groot, 2009). In this way, executive powers would be formally transferred to the executive body made up of (semi)professionals who no longer participate in normal council work. Ordinary councillors, on the other hand, could focus on their core-tasks. This personal and functional separation partly fits with the present reality. Indeed, the persisted prevalence of the layman rule does no longer seem to harmonize with the reality of diverging local mandates and the dichotomy between ordinary powerless councillors and a local powerful elite. However, whilst dualism could counter the executive dominance, it might not be sufficient to overturn the partitocratic nature of our local government system.

The alternative path advocates a new role for councillors in governance: the role of 'metagovernor'. This role implies linking governance networks to representative government and is considered as the optimal way to ensure both democratic legitimacy and effectiveness in network decision-making (Hovik \& Vabo, 2005; Sörensen \& Torfing, 2009). In a nutshell, councillors act as managers of democracy in those networks instead of being the cornerstone of the latter (Sörensen, 2006). However, some problems with this concept exist. First, most metagovernance theories and studies seem to be inspired by a normative underpinning whilst systematic empirical research is yet to catch on. Second, 
metagovernance seems predominantly a North-European (and especially Scandinavian) phenomenon. Since governance authors point to the institutional context as a fundamental precondition for metagovernance (Klijn \& Koppenjan, 2000; Wälti et al., 2004; Sörensen \& Torfing, 2009), one could doubt if the concept complies with the typical tradition of Belgian local government. For instance, Belgian legislation still emphasizes the preference for traditional local government and its inherent councillor role-set. Third, our descriptive analysis revealed that councillors very much support their own classic role-set as well. It is first and foremost the informal decision-making culture that instigates the democratic deficit in councillors' role-fulfilment. Finally, even in the changing context of governance, traditional government and its institutions will hardly become obsolete: "traditional government structures are still very much present, and in many instances, government seems to be a more appropriate concept than governance" (Jacobsen, 2009: 237).

Therefore, follow-up research is needed to further our insights in the effects of government reforms, and to map out and evaluate the optimal path to establish democratic governance. Nonetheless, for the time being it is apparent that Belgian local councillors hardly function as the foundation of local democracy.

\section{Notes}

${ }^{1}$ The friction between councillor roles and governance also works the other way around, inclining problems for the process of governance itself. In governance, the actors involved must enjoy a certain amount of freedom to make spontaneous decisions, but this risks to hollow out the democratic control - usually performed by the council(lors) - on the policy decided upon (Andrew \& Goldsmith, 1998; Sörensen \& Torfing, 2003). Wälti et al. (2004) call this the deliberative criticism on governance, referring to the limited accountability of decision-making in governance. The participatory criticism, on the other hand, counters limited citizen participation - as often only involved citizens are included in governance networks. Moreover, "there is no free and open competition among different political elites to represent the relevant and affected citizens", another crucial prerequisite for representative democracy (Sörensen \& Torfing, 2009: 243).

${ }^{2}$ Flanders introduced the Municipal Decree in 2005, and Wallonia introduced the Walloon Code of Local Democracy in 2006. The Brussels' Capital Region did not introduce substantial institutional reforms yet.

${ }^{3}$ For further research 'Municipal Assemblies in European Local Governance' (MAELG), see www.maelg.eu.

${ }^{4}$ The population of Belgian municipalities (589) was grouped in 62 strata on the base of three selection variables: population, region and socio-economic character. The strata were internally as homogenous as possible, whilst being externally maximal heterogeneous. Three (or exceptionally two) municipalities out of each stratum were selected randomly. Mayors and aldermen were also addressed as they retain their seats in the council whilst being executives. The questionnaires were sent out in June 2008. Afterwards, two moments of follow-up (September 2008 and December 2008) increased response to $21 \%$. 
5 'Flanders' represents councillors from a municipality in the Flemish region and is constructed by the authors based on the respondents' municipality $(\mathrm{N}=565$ or $66.5 \%)$; 'Populous' represents the third of respondents of the biggest municipalities in terms of inhabitants, i.e. $>19.357$, created by the authors based on the respondents' municipality $(\mathrm{N}=284$ or $33.7 \%$ ); 'Support' represents respondents who gave a score $>2$ (scale $0-4$ ) on the question 'People have different ideas about how local democracy should function. Please indicate how important for local democracy you feel the following requirements are: Residents should participate actively and directly in making important local decisions.' $(\mathrm{N}=354$ or $42.3 \%)$; 'Talking/brokerage' represents the professional categories Professional politician, Civil servant, Business manager, Teacher and Liberal profession ( $\mathrm{N}=439$ or $52 \%)$; 'University' represents respondents with University/college or equivalent as highest completed education $(\mathrm{N}=543$ or $64.3 \%)$; 'Experienced' represents the third of respondents with most experience as councillors, i.e. $>13$ years $(\mathrm{N}=285$ or $33.6 \%)$; 'Majority' presents respondents who are member of a party of the political majority in the council, created by the authors based on the comparison of the respondents' political party and the political majority in the municipality $(\mathrm{N}=518$ or $63.7 \%)$; 'BMA' represents respondents who presently hold or previously held a mandate as a Member of the executive board ( $\mathrm{N}=277$ or $33.3 \%)$;

${ }^{6}$ The dependent variables represent respondents who gave a score $>2$ on the question on 'role attitude' (For Representation N=745 or $88.3 \%$; For Policy $\mathrm{N}=651$ or $77.9 \%$; For Control $\mathrm{N}=673$ or $80.2 \%$ ) and 'role behaviour' (For Representation $\mathrm{N}=558$ or $66.3 \%$; For Policy $\mathrm{N}=330$ or $39.2 \%$; For Control $\mathrm{N}=442$ or $52.2 \%$ ) as stated in section 4 ; and respondents with a score $>1$ on the newly created variable 'role discrepancy' (For Representation $\mathrm{N}=98$ or $11.8 \%$; For Policy $\mathrm{N}=225$ or $27.2 \%$; For Control $\mathrm{N}=129$ or $15.5 \%$ ).

${ }^{7}$ The executives are elected by the council. Yet in practice, the majority parties distribute the executive mandates. As such executives are almost always member of a majority party.

\section{References}

Aars, J. \& Fimreite, L. (2005) Local Government and Governance in Norway: Stretched Accountability in Network Politics, Scandinavian Political Studies, 28(3), pp. 239-256, doi: $10.1111 / \mathrm{j} .1467-9477.2005 .00131 . x$.

Andrew, C. \& Goldsmith, M. (1998) From Local Government to Local Governance - and Beyond?, International Political Science Review, 19(2), pp. 101-117, doi: 10.1177/019251298019002002.

Bäck, H., Heinelt, H. \& Magnier, A. (2006) The European Mayor. Political Leaders in the Changing Context of Local Democracy (Wiesbaden: VS Verlag für Sozialwissenschaften).

Copus, C. (2008) English Councillors and Mayoral Governance: Developing a New Dynamic for Political Accountability, The Political Quarterly, 79(4), pp. 590-604, doi: 10.1111/j.1467-923X.2008.00961.x.

Cotta, M. \& Best, H. (2000) Parliamentary Representatives in Europe 1848-2000: Legislative Recruitment and Careers in Eleven European Countries (New York: Oxford University Press).

De Groot, M. (2009) Democratic Effects of Institutional Reform in Local Government. The Case of the Dutch Local Government Act 2002 (Enschede: PrintPartners Ipskamp).

Denters, B. (2006) Duo or Duel? The Relations between Mayors and Councils in Democratic Local Government, In: Bäck, H., Heinelt, H. \& Magnier, A. (eds) The 
European Mayor. Political Leaders in the Changing Context of Local Democracy, pp. 271-285 (Wiesbaden: VS Verlag für Sozialwissenschaften).

Denters, B. \& Klok, P. J. (2003) A new role for municipal councils in Dutch local democracy?, In: Kersting, N. \& Vetter, A. (eds) Reforming Local Government in Europe. Closing the Gap between Democracy and Efficiency, pp. 65-84 (Opladen: Leske \& Budrich).

Denters, B. \& Rose, L. E. (2005) Local Governance in the Third Millennium: a brave new world?, In: Denters, B. \& Rose, L. (eds) Comparing Local Governance. Trends and developments, pp. 1-11 (Hampshire: Palgrave Macmillan).

De Rynck, F. (2000) Het krachtenveld in de gemeente, In: De Rynck, F. \& Bouckaert, G. (eds) Praktisch handboek voor gemeentebeleid, pp. 3-23 (Brugge: Die Keure).

De Rynck, F. (2007) Burgerparticipatie voorbij de representatie? De interactie tussen stadsbesturen en burgerparticipatie: wisselstroom of kortsluiting? (Brugge: Vanden Broele).

De Rynck, F. \& Voets, J. (2006) Democracy in Area-Based Policy Networks. The Case of Ghent, The American Review of Public Administration, 36, pp. 58-78, doi: $10.1177 / 0275074005282585$.

De Winter, L. \& Dumont, P. (2006) Do Belgian Parties Undermine the Democratic Chain of Delegation?, West European Politics, 29(5), pp. 957-976, doi: 10.1080/01402380600968844.

Goldsmith, M. J. \& Page, E. C. (2010) Changing Government Relations in Europe. From Localism to Intergovernmentalism (Oxon: Routledge).

Guérin, E. \& Kerrouche, E. (2008) From Amateurs to Professionals: The Changing Face of Local Elected Representatives in Europe, Local Government Studies, 34(2), pp. 179201, doi: 10.1080/03003930701852260.

Hansen, K. (2001) Local Councillors: Between Local 'Government' and Local 'Governance', Public Administration, 79(1), pp. 105-123, doi: 10.1111/14679299.00248.

Hansen, K. (2005) Representative Government and Network Governance - In Need of 'Cogovernance': Lessons from Local Decision Making on Public Schools in Denmark, Scandinavian Political Studies, 28(3), pp. 219-237, doi: 10.1111/j.14679477.2005.00130.x.

Haus, M., Heinelt, H. \& Stewart, M. (2005) Urban Governance and Democracy (Oxon: Routledge).

Hendriks, F. (2002) Representatieve politiek in de netwerksamenleving: Problemen en perspectieven, Bestuurskunde, 11(7), pp. 265-279.

Hesse, J. \& Sharpe, L. (1991) Local Government in International Perspective: Some Comparative Observations, In: Hesse, J. (ed.) Local Government and Urban Affairs in International Perspective. Analysis of Twenty Western Industrialised Countries, pp. 605-608 (Baden-Baden: Nomos-Verlagsgesellschaft).

Heywood, A. (2002) Politics (Houndmills: MacMillan Foundations).

Hovik, S. \& Vabo, I. (2005) Norwegian Local Councils as Democratic Meta-governors? A Study of Networks Established to Manage Cross-border Natural Resources, Scandinavian Political Studies, 28(3), pp. 257-275, doi: 10.1111/j.14679477.2005.00132.x.

Jacobsen, D. I. (2009) A Tragedy of the Councils? Exploring the Hollowing-OutHypothesis - The Case of Norwegian Local Authorities, Lex Localis - Journal of Local Self-Government, 7(3), pp. 221-242. 
Kalk, E. \& De Rynck, F. (2003) Burgerbetrokkenheid en bewonersparticipatie in de Vlaamse steden, In: De Rynck, F. (ed.) De eeuw van de stad. Over stadsrepublieken en rastersteden. Voorstudies, pp. 453-479 (Brussel: Ministerie van de Vlaamse Gemeenschap - Project Stedenbeleid).

Klijn, E. H. (2008) Governance and governance networks in Europe. An assessment of ten years of research on the theme, Public Management Review, 10(4), pp. 505-525, doi: 10.1080/14719030802263954.

Klijn, E. H. \& Koppenjan, J. F. M. (2000) Politicians and Interactive Decision Making: Institutional Spoilsports or Playmakers?, Public Administration, 78(2), pp. 365-387, doi: $10.1111 / 14679299.00210$.

Mouritzen, P. \& Svara, J. (2002) Leadership at the Apex: Politicians and Administrators in Western Local Governments (Pittsburgh: University of Pittsburgh Press).

Page, E. C. \& Goldsmith, M. J. (1987) Centre and Locality: Functions, Access and Discretion, In: Page, E. C. \& Goldsmith M. J. (eds) Central and Local Government Relations. A Comparative Analysis of Western European Unitary States, pp. 3-11 (London: Sage Publications).

Pilet, J. B. (2008) Les évolutions récentes du régime politique local en Wallonie. Vers un système parlementaire local avec un leader fort? (Brugge: Vanden Broele).

Plees, Y. (2005) Belgium: the changing world of Belgian municipalities, In: Denters, B. \& Rose, L. (eds) Comparing Local Governance. Trends and developments, pp. 47-64 (Hampshire: Palgrave Macmillan).

Pratchett, L. (1999) Introduction: Defining democratic renewal, Local Government Studies, 25(4), pp. 1-18, doi: 10.1080/03003939908433963.

Putnam, R. D. (1976) The Comparative Study of Political Elites (New Jersey: PrenticeHall, Inc).

Rao, N., Young, K., Lynn, P. \& Hurrell, P. (1994) Place, personal characteristics and councillor roles: a multivariate analysis of survey data, Policy and Politics, 22(2), pp. 31-42.

Sörensen, E. (2006) Metagovernance: The Changing Role of Politicians in Processes of Democratic Governance, The American Review of Public Administration, 36, pp. 98114, doi:10.1177/0275074005282584.

Sörensen, E. \& Torfing, J. (2003) Network Politics, Political Capital, and Democracy, International Journal of Public Administration, 26(6), pp. 609-634, doi: 10.1081/PAD120019238.

Sörensen, E. \& Torfing, J. (2009) Making Governance Networks Effective and Democratic Through Metagovernance, Public Administration, 87(2), pp. 234-258, doi: 10.1111/j.1467-9299.2009.01753.x.

Steen, T. \& Wille, A. (2005) Strengthening Local Government in the Netherlands and Flanders: Similar Problems, Different Solution?, In: Reynaert, H., Steyvers, K., Delwit, P. \& Pilet, J. B. (eds) Revolution or Renovation? Reforming Local Politics in Europe, pp. 445-469 (Brugge: Vanden Broele).

Steyvers, K. (2007) Wat is lokale politiek? In: Reynaert, H. (ed.), De kerktorenpolitiek voorbij? Lokale politiek in Vlaanderen, pp. 17-40 (Brugge: Vanden Broele).

Steyvers, K. \& Reynaert, H. (2003) Het gemeentedecreet: gerealiseerde ambities?, In: Reynaert, H. \& Steyvers, K. (eds) Het gemeente- en provinciedecreet: gerealiseerde ambities? pp. 1-48 (Brugge: Vanden Broele).

Steyvers, K., Reynaert, H. \& Block, T. (2010) Team Work or Territorial War? Assessing the introduction of a Management Team in Local Government: the Flemish region of 
T. Verhelst, H. Reynaert \& K. Steyvers: Foundation or Fragment of Local Democracy? Empirically Assessing the Roles of Local Councillors in Belgian Governance

Belgium, Public Management Review, 12(1), pp. 11-31, doi: 10.1080/14719030902798297.

Steyvers, K., Reynaert, H., De Ceuninck, K. \& Valcke, T. (2006) Mayors in Governance: Heading for Efficiency and Democracy? The Belgian Case, Local Government Studies, 32(4), pp. 429-445, doi: 10.1080/03003930600792997.

Suykens, M. (2001) De regionalisering van de gemeentewet: naar een grotere bestuurskracht voor de Vlaamse gemeenten?, In: Reynaert, H. \& Devos, C. (eds) Lokale en Provinciale Politiek. Uitdagingen voor de 21ste eeuw, pp. 1-20 (Brugge: Vanden Broele).

Tops, P. \& Zouridis, S. (2002) De binnenkant van politiek (Amsterdam: Atlas).

Vetter, A. \& Kersting, N. (2003) Democracy versus efficiency? Comparing local government reforms across Europe, In: Kersting, N. \& Vetter, A. (eds) Reforming Local Government in Europe. Closing the Gap between Democracy and Efficiency, pp. 11-29 (Opladen: Leske \& Budrich).

Wälti, S., Kübler, D. \& Papadopoulos, Y. (2004) How Democratic Is «Governance»? Lessons from Swiss Drug Policy, Governance: An International Journal of Policy, Administration and Institutions, 17(1), pp. 83-113, doi: 10.1111/j.09521895.2004.00238.x. 